\author{
Павлюк Тетяна Серхї̈вна \\ кандидат мистецтвознавства, \\ Київський національний університет \\ культури і мистеитв, \\ вул. С. Коновальия,36, Київ, Україна, 01133, \\ https://orcid.org/0000-0002-3940-9159 \\ 24caratsofart@gmail.com
}

\title{
СПЕЦИФІКА КОНКУРСНИХ ТАНЦЮВАЛЬНИХ СЕКВЕНЦЙ СТИЛЮ НЬЮ-ВОУГ
}

Метою статті є виявлення специфіки австралійського стилю (Нью-Воуг) виконання конкурсних спортивних бальних танців; проведення мистецтвознавчого аналізу техніки виконання конкурсних танцювальних секвенцій стилю Нью-Воуг. Методологія дослідження базується на принципах об’єктивності, історизму, багатофакторності, а для досягнення мети - використані методи наукового пізнання: проблемно-хронологічний, конкретно-історичний, описовий, логіко-аналітичний. Наукова новизна. Вперше проведено мистецтвознавче дослідження Австралійського стилю конкурсних спортивних бальних танців Нью-Воуг (New Vogue); визначено особливості формування стилю в історичній ретроспективі та виявлено внесок провідних танцюристів і вчителів бальних танців - членів професійних танцювальних організацій Австралії в процесі його канонізації, розглянуто композиційні особливості та специфіку техніки виконання 15-ти конкурсних танцювальних секвенцій у ритмі Повільного фокстроту, Танго, Віденського Вальсу та Маршу. Висновки. Визначено особливості австралійського стилю виконання спортивних бальних танців НьюВоуг та його відмінності від Міжнародного та Американського: усталеність композицій та різноманіття позицій в парі, зокрема роз'єднання партнерів під час виконання танців; використання танцювальними парами відкритих позицій; можливість виконавців змінювати стиль рухів руками відповідно до власної індивідуальності, що сприяє посиленню видовищності виступів та створенню ефектних художніх образів.

Ключові слова: Австралійський стиль; Нью-Воуг; конкурсні спортивні бальні танці; танцювальні секвенції; кодифікація; хореографія.

Павлюк Татьяна Сергеевна, кандидат искусствоведения, Киевский национальный университет культуры и искусств, ул. Е. Коновальиа, 36, Киев, Украина

\section{Специфика конкурсных танцевальных секвенций стиля Нью-Воуг}

Целью статьи является выявление специфики австралийского стиля (Нью-Воуг) выполнения конкурсных спортивных бальных танцев; проведение искусствоведческого анализа техники выполнения конкурсных танцевальных секвенций стиля Нью-Воуг. Методология исследования базируется на принципах объективности, историзма, многофакторности, , а для достижения цели - использованы методы научного познания: проблемно-хронологический, конкретно-исторический, описательный, логикоаналитический. Научная новизна. Впервые проведено искусствоведческое исследование австралийского стиля конкурсных спортивных бальных танцев Нью-Воуг (New Vogue), определены особенности формирования стиля в исторической ретроспективе и выявлен вклад ведущих танцоров и учителей бальных танцев - членов профессиональных танцевальных организаций Австралии в процессе его канонизации; рассмотрены композиционные особенности и специфика техники выполнения 15-ти конкурсных танцевальных секвенций в ритме Медленного фокстрота, Танго, Венского вальса и Марша. Выводы. Определены особенности австралийского стиля исполнения спортивных бальных танцев Нью-Воуг и его отличия от Международного и Американского: устойчивость композиций и разнообразие позиций в паре, в том числе разъединение партнеров во время исполнения танцев; использование танцевальными парами открытых позиций; возможность 
ISSN 2410-1176 (Print) Вісник КНУКіМ. Серія Мистецтвознавство. Вип. 39. ISSN 2616-4183 (Online)

исполнителей менять стиль движений руками в соответствии с собственной индивидуальности, что способствует усилению зрелищности выступлений и созданию эффектных художественных образов.

Ключевые слова: Австралийский стиль; Нью-Воуг; конкурсные спортивные бальные танцы; танцевальные секвенции; кодификация; хореография.

Pavliuk Tetiana, PhD in Art Criticism, Kyiv National University of Culture and Arts, 36, Y. Konovaltsia St, Kyiv, Ukraine

The specifics of competitive dance sequences of the New Vogue style

The purpose of the article is to identify the specifics of the Australian style of performing competitive ballroom dances (New Vogue); to conduct an art critical analysis of the technique of performing competitive dance sequences of the New Vogue style. The research methodology was based on the principles of objectivity, historicism, multifactorness, systematicity, complexity, development and pluralism; to fulfill the research purpose, the following methods of scientific knowledge were used: problem-chronological, concrete-historical, statistical, descriptive, and logical-analytical. The scientific novelty of the work lies in the first attempt to carry out an art critical study of the New Vogue Australian style of competitive ballroom dancing; to determine the peculiarities of the formation of the style in the historical retrospective; to identify the contribution of leading dancers and ballroom dance teachers - members of professional dance organizations of Australia - in the process of its canonization; to consider the compositional features and specifics of the technique of performing fifteen competitive dance sequences in the rhythm of Slow Foxtrot, Tango, Viennese Waltz, and March. Conclusions. The features of the New Vogue Australian style of performing competitive ballroom dances and its distinction from the International and American styles were identified: constancy of compositions and multiplicity of positions in dance couples, including the separation of partners during dance performance; use of open positions by dance couples; the ability of performers to change the style of movements in accordance with their own individuality, which contributes to the enhancement of the visual appeal of performances and the creation of spectacular artistic images.

Key words: Australian style; New Vogue; competitive ballroom dancing; dance sequences; codification; choreography.

Вступ. Еволюція спортивного бального танцю, витоки та формування якого безпосередньо пов'язані 3 побутовим бальним танцем минулих століть і має чітке спрямування від соціальних танцювальних до професійних, конкурсних форм, та специфіка світових стилів виконання спортивних бальних танців, на сучасному етапі, у контексті активізації міжкультурного комунікативного дискурсу, є одними з важливих та водночас недостатньо вивчених тем в галузі хореографічного мистецтва. Відтак, дослідження становлення та розвитку Австралійського стилю, відомого також як Нью-Воуг (New Vogue, від англ. New Vogue Dances - танці нової моди) - одного з трьох світових стилів виконання спортивного бального танцю, поруч із Міжнародним та Американським стилем, а також висвітлення специфіки техніки виконання конкурсних танцювальних секвенцій, на нашу думку є актуальним та необхідним.

Мета дослідження - виявлення специфіки австралійського стилю (Нью-Воуг) виконання конкурсних бальних танців; проведення мистецтвознавчого аналізу техніки виконання конкурсних танцювальних секвенцій стилю Нью-Воуг.

Аналіз праць вітчизняних науковців засвідчує наявність багатьох досліджень, в яких розглядаються окремі аспекти історії формування спортивного бального танцю та аналізуються специфіка техніки виконання й методика викладання бальних танців Міжнародного стилю - Європейської та Латиноамериканської програми. Окремі аспекти історії фомування танців стилю Нью-Воуг досліджено зарубіжними науковцями: Н. Бойд «Танцювальні секвенції Нью-Воуг» («New Vogue Sequence Dancing»), 1984 р. та «Танцювальні секвенції Нью-Воуг та Віденський Вальс» («New vogue sequence dancing \& the Viennese waltz»), 2006 р.; К. Лімон та Л. Батлер «Танці для розваги» («Dances for 
Entertainment»), 1988 р.; Д. Хербісон-Еванс «Австралійські танці Нью-Воуг на Веб» («Australian New Vogue Dancing on the Web»), 2001 р. та ін. Проте й досі не було проведено комплексне дослідження Австралійського стилю та специфіки конкурсних танцювальних секвенцій, як у мистецтвознавчому, так і культурологічному аспекті.

Виклад основного матеріалу. Світовим стилем виконання спортивного бального танцю поруч із Міжнародним та Американським визнано австралійський стиль, відомий як Нью-Воуг (New Vogue, від англ. New Vogue Dances - танці нової моди), який на сучасному етапі отримав надзвичайну популярність на території Австралії та Нової Зеландії - його включено в усі професійні, аматорській та професійно-аматорські танцювальні змагання та чемпіонати. Характерною відмінністю Австралійського стилю від спорідненого 3 ним Міжнародного, є усталеність композицій та різноманіття позицій в парі, зокрема роз'єднання партнерів під час виконання танців.

Дослідження тенденцій розвитку спортивного бального танцю загалом та австралійського стилю, зокрема, на сучасному етапі передбачає чітке розмежування традиційного, що пов'язано з вивченням походження, історією розвитку бального танцю та новаторського, яке позиціонуємо як невід'ємну умову еволюційного процесу, - історикокультурні, соціальні, організаційні зміни та особистий творчий внесок у розвиток техніки виконання та хореографію спортивного бального танцю провідних танцюристів і викладачів.

Позиціонуючи Нью-Воуг як унікальний австралійський стиль сучасних бальних танців, зазначимо, що він $є$ однією 3 форм розвитку напрямку секвея (Sequence Dancing), заснованого на встановленому шаблоні кроків (так званих скриптів). У даному напрямку традиції історико-побутових танців поєднано з можливостями танцювальних секвенцій наразі існує більш ніж 150 різноманітних танців, розподілених на три категорії: класичні танці (Старовинний вальс, Кадриль, Галоп, Полька, Саунтер, Гавот, Ту степ, Мазурка, Шоттіше та ін.), сучасні танці (Вальс, Танго, Фокстрот, Квікстеп) та латиноамериканські танці (Румба, Ча-ча-ча, Самба, Джайв, Пасодобль, Боса-Нова, Сальса, Мамбо), в яких усі танцювальні пари виконують єдиний хореографічний сценарій, усталений для кожного конкретного танцю. Федерацією танцювального спорту Австралії (DanceSport Australia) було визначено 15-ть бальних секвенцій для виконання на чемпіонатах країни зі спортивних бальних танців в одній з трьох основних категорій, разом з Європейською - Professional Standard (Повільний вальс, Танго, Повільний фокстрот, Квікстеп, Віденський Вальс) та Латиноамериканською - Professional Latun (Самба, Ча-ча-ча, Румба, Пасадобль, Джайв) категорією Нью-Воуг: бальні секвенції в ритмі Повільного фокстроту - «Барклай-блюз» (Barclay Blues), «Карусель» (Carousel), «Мерилін» (Merrilyn), «Чармейн» (Charmaine), «Ексельсіор-Шоттіш» (Excelsior Schottische); Віденського вальсу: «Вальс у сутінках» (Twilight Waltz), «Вальс Люсіль» (Lucille Waltz), «Вальс Трейсі Лі» (Tracie Leigh Waltz), «Парма Вальс» (Parma Waltz), «Свінг-Вальс» (Swing Waltz); Маршу: «Вечірній Тристеп» (Evening Three Step), «Джипсі-Tеп» (Gypsy Tap) та в ритмі Танго: «Ла-Бомба» (La Bomba), «Приголомшливе Танго» (Tango Terrific), «Танджет» (Tangoette).

Танці стилю Нью-Воуг - це своєрідний симбіоз танців Старого часу (Old Time), тобто танцювальних секвенцій (Sequence Dancing) та спортивних бальних танців Європейської та Латиноамериканської програми, в якому використовується той самий тип музичного супроводу, а кожна танцювальна пара виконує визначену послідовність кроків одночасно, повторюючи іiі певну кількість разів. Характерною відмінністю від Міжнародного та Американського стилів бальних танців $є$ можливість виконавців змінювати стиль рухів руками відповідно до власної індивідуальності або для посилення художнього образу.

На сучасному етапі стиль Нью-Воуг отримав надзвичайну популярність на території Австралії та Нової Зеландії - його включено в усі професійні, аматорській та професійноаматорські танцювальні змагання та чемпіонати.

Н. Бойд зазначає, що витоки танцювальних секвенцій стилю Нью-Воуг сягають XIX ст., коли ангійські танці Старого часу були привезені колоністами на Австралійський континент та отримали масштабну популяризацію. У 1930-1940-х рр. ХХ ст., завдяки 
діяльності визначних австралійських танцюристів, які у формі своєрідного протесту проти неприродніх балетних позицій, що використовувалися в старовинних танцях, почали здійснювати постановки у новій хореографії, заснованій на сучасній їм стандартній техніці виконання бальних танців, починається період формування стилю Нью-Воуг, назву якого запропонував танцюрист та вчитель бальних танців Лін Хоріган із Брісбена (1930-ті рр.) (Boyd, 1984, p. 34).

Протягом кількох десятиліть австралійські хореографи Б. Кертледж, Н. Локк, Б. Рейлі, К. Лімон, Л. Батлер, М. Херд, Д. Бартлет та ін. створили понад 350 різноманітних варіантів танців на всі танцювальні ритми для соціальних та конкурсних програм, багато 3 яких було представлено на регулярних змаганнях, які проводилися спеціально для показу бальних танців у новій хореографії. Таким чином було визначено обмежену кількість найпопулярніших танців, кроки та фігури стандартизовано - процес кодифікації було розпочато членами Австралійської танцювальної ради (Australian Dance Council) в 1967 р., видано рекомендації, інструкції та посібники з описом техніки виконання, наприклад: «Пошагова інструкція 3 навчання танцям: 40 танців Нью-Воуг для соціальних танцюристів якщо вони танцюють сьогодні» («А step by step dance instruction book : 40 new vogue (old time) dances for the Social dancer as they are danced today») К. Лімона та Л. Батлета (1986, 156 p.).

Соціальні танці австралійського стилю мають послідовність 8, 16 або 32 такти, а конкурсні переважно 16-ть - бальні секвенції в ритмі Повільного фокстроту, Танго, Маршу, музичний розмір яких 4/4 та 32 такти - бальні секвенції в ритмі Віденського Вальсу, музичний розмір 3/4, тому для супроводу необхідна музика 3 подібним фразуванням. Виключенням є «Вечірній три степ» (Evening Three Step), бальна секвенція в ритмі Маршу на 8 тактів, музичний розмір 4/4, який виконується в помірно швидкому темпі, лірично та натхненно, $з$ широким пересуванням на танцювальному майданчику.

Аналізуючи Аавстралійський стиль зазначимо, що простіші у виконанні танці, які зазвичай належать виключно до соціальних, складаються з послідовності стандартизованих кроків, фігур та варіацій сучасних бальних та латиноамериканських танців Міжнародного стилю, а також деяких хореографічних елементів бальних танців категорій American Smooth та American Rhythm американського стилю.

Про популярність стилю Нью-Воуг у соціальній сфері хореографії в Австралії на сучасному етапі свідчить той факт, що, наприклад у місті Бандаберг (штат Квінсленд), 3 населенням понад 47000 осіб, щовечора, в найкращих танцювальних залах відбуваються танцювальні вечори «New Vogue».

Неабияке значення у процесі стандартизації конкурсних танців Австралійського стилю відіграла діяльність Н. Бойда - члена Австралійської танцювальної ради (Australian Dancing Board), кваліфікованого експерта Британської ради бальних танців (British Council of Ballroom Dancing), професора Академії танцювальних майстрів Франції (L'academie des maitres de dance de France). У його хореографічному доробку, у 1978-1979 рр., Федерацією танцювального спорту Австралії було стандартизовано танцювальні секвенції, які й на сучасному етапі входять до конкурсної програми Нью-Воуг. В оригінальній хореографії Н. Бойда було стандартизовано танцювальну секвенцію в ритмі Танго «Приголомшливе Танго». Авторами інших танців є хореографи та професійні танцюристи з Великобританії, України та Австралії, які розробили постановки бальних секвенцій протягом ХХ ст. Так, наприклад, «Вечірній Три-Степ» засновано на танці «Сва Три-Степ», постановку якого у 1904 р. здійснив хореограф з Великобританії С. Паінтер; оригінальна хореографія «Парма Вальсу» (1920р.), який було відзначено дипломом 1-го класу на 28-й щорічній конференції Британської асоціації танців у червні 1920 р. належить Н. Локу з Великобританії; «ДжипсіТепу» (1937 р., Пасадобль) - професору Болоту (Болотінский) з України; «Танджету» танцюристу з Мельбурна Г. Хеллеру (1930-ті рр.); «Ла-Бомба» (1938 р., Квадратна Румба) та «Барклай-блюзу» (1943р.) - Д. Кеннеді з Сіднея; «Ексельсіор-Шоттішу» (1939 р.) Ч. Томпсону з Сіднея; «Чармейну» (1935 р.) - Н. Чапплу; «Каруселі» (1975 р.) - професійним танцюристам Джеку та Джойс Галлік із Мельбурна; «Вальсу у сутінках» (1944р.) - 
Д. Бартлету; «Вальсу Трейсі Лі» (1962р.) - Берні та Берті Рейлі з Мельбурну; «Вальсу Люсіль» (1930-ті рр.) - Б. Картледжу. Сдиної думки щодо авторства хореографії «СвінгВальсу» (1939 р.) серед дослідників немає. Наприклад, К. Лімон (1988, р. 156) називає прізвище Д. Кеннеді, а Н. Бойд (2008, р. 13) - Т. Кірка та В. Сімс. Подібні протиріччя існують і щодо авторства постановки бальної секвенції в ритмі Повільного фокстроту «Мерилін». К. Лімон (1988, р. 156) вважає, що її було поставлено в 1964 р. танцюристкою 3 Сіднея С. Місдейл, але існують свідчення, що ії автором є мельбурнський хореограф Д. Фехі, який здійснив постановку в 1941-1942 pр., і назвав її на честь своєї доньки (Herbison-Evans, 1999).

Стандартизовані танцювальні секвенції були детально описані Н. Бойлом у працях: «Танцювальні секвенції Нью Воуг» (старі часи): переглянута методика шести конкурсних танців» («New Vogue (old time) sequence dancing : the revised technique of six competition dances» (1980, 48 р.) та «Танцювальні секвенції Нью Воуг» (старі часи): переглянута методика дванадцяти конкурсних танців» («New Vogue (old time) sequence dancing : the revised technique of twelve championship dances») (1979, 96 р.). Варто зазначити, що Н. Бойд також $\epsilon$ автором та видавцем теоретичних та навчально-методичних праць: «Танцювальні секвенції Нью-Воуг та Віденський Вальс» («New Vogue Sequence Dancing and the Viennese Waltz»), в якій зроблено детальний опис усіх фігур танцювальних секвенцій в ритмі Віденського вальсу відповідно до вимог Міжнародної федерації танцювального спорту та Федерації танцювального спорту Австралії, а також техніки виконання танців, схваленої Австралійською та Новозеландською танцювальними радами (2006, 192 р.), «Керівництво 3 техніки навчання» («Guidelines for technique studies»), в якій проаналізовано техніку виконання бальних танців (Стандарт), стилю Нью-Воуг та Латиноамериканських танців, а також розглянуто важливі аспекти суддівства на чемпіонатах та змаганнях зі спортивних бальних танців (2000, 112 р.), «Латиноамериканські танці» («Latin-American Dancing»), «Бальні танці» («Ballroom Dancing»), «Англійські танцювальні секвеї Старого часу» («English Old Time Sequence Dancing») та ін.

Варто зазначити, що в процесі стандартизації танців стилю Нью-Воуг було застосовано систему «Лабанація або Кінетографія» (Labanotation or Kinetography), розроблену в 1928 р. угорським танцюристом, вчителем танців та хореографом Р. Лабаном, новації якої полягали у можливості нотації не лише позицій тіла та структури кроків, а й виконання рухів (наприклад, сильні або розслаблені рухи та їх акцентація). Зазначимо, що станом на 1960-ті рр., за сприянням Бюро танцювальної нотації (Dance Notation Bureau) система була розширена, що дозволило при записі передавати також зміст та мотивації рухів (Hutchinson, 1970, pp. 164-170). Відтак, завдяки використанню абстрактних символів системи хореографами Австралійської танцювальної ради було започатковано напрямок та рівень руху танцювальних секвенцій, частини тіла які виконують рухи, тривалість рухів та їх динамічні якості.

Бальні секвенції в ритмі Віденського Вальсу в Австралійському стилі спортивного бального танцю репрезентовано танцями, хореографічні сценарії яких були складені в різні часи, з використанням різноманітних рухів, проте вони всі мають правильні кути відносно лінії танцю.

Наприклад, «Вальс у сутінках», хореографічний сценарій якого був складений танцюристом Д. Бартлетом у 1944 р., складається 3 7-ми рухів: 1) Хід (Walks) - Шассе (Chasse): три кроки виконуються за схемою «крок - приставка - крок» - одна нога ніби переслідує іншу - Закритий вперед (Forward close); 2) Оборотній віденський крос (Reverse viennese cross) - Крок назад у протилежному напрямку (Back step to oversway); 3) Хід (Walks) - Шасcе (Chasse) - Forward close (у протилежному напрямку); 4) Оборотній віденський крос (Reverse viennese cross) - Крок назад у протилежному напрямку (Back step to oversway); 5) Шассе (Chasse), Обличчям до обличчя (Face to Face) - Крос-крок назад (Back Cross Back) - Шассе (Chasse), Обличчям до обличчя (Face to Face) - Перехід навхрест вперед (Forward Cross): на противагу повному переходу навхрест, партнерка стає перед партнером, виконує перехід під правою рукою партнера (повертається праворуч) та під лівою рукою 
партнера (повертається ліворуч); 6) Хід вперед (Forward Walks) та Повітряний (Aerial) - Хiд назад (Backward Walks) - Поворот партнерки під рукою (Lady Underarm Turn); 7) Фінальний pyx (Final Movement) - Зворотний (лівий) поворот (Reverse Viennese Waltz): послідовність кроків, під час яких пара виконує поворот ліворуч.

У 1965 р. танцювальною парою Бернард та Бетті Рейлі було розроблено хореографічний сценарій танцю «Вальс Трейсі Лі», названого на честь їх доньки - 6-ть рухів танцю складаються з таких кроків як: 1) Хід вперед (Forward Walks) - Крос-Степ (Cross Step - крок навхрест, при виконанні якого робоча нога танцюриста перетинає лінію руху його опорної ноги) - Повітряний (Aerial); 2) Крос-Степ Назад (Back Cross Step) - Сольний поворот (Solo Turn): роздільні повороти партнера та партнерки довкола себе, які виконуються в дзеркальному відображенні; 3) повторюються такти 1-8 проти лінії танцю 3 іншої ноги - Чек (Check) та Шассе (Chasse); 4) Чек (Check) та Шасcе (Chasse); 5) Хід та Повітряний (Walks and Aerial) Поворот партнерки під рукою; 6) Зворотний поворот (Reverse Turn Viennese Waltz).

Однією 3 важливих відмінностей конкурсних танців Нью-Воуг від стандартних бальних танців є використання танцювальними парами багатьох відкритих позицій, що сприяє посиленню видовищності виступів та створенню ефектних художніх образів.

Австралійською танцювальною радою для конкурсних танців стилю Нью-Воуг було стандартизовано такі положення танцювальних пар як: Закрита позиція (Closed Ballroom hold) - потребує підтримки 5-ти пунктів контакту між танцювальними партнерами під час виконання танцю або рухів (три для рук: ліва рука партнера тримає праву руку партнерки; ліва рука партнерки спирається на верхню частину правого плеча партнера, або за його плечем в Танго; права рука партнера розміщена на спині партнерки з лівої сторони; та ще два: лівий лікоть партнерки впирається на правий лікоть партнера; права частина грудної клітини партнерів зустрічаються), а також таких аспектів як невеликий поворот голови обох партнерів та нахил тулуба ліворуч; позиція променада (Promenade hold) - зберігаються контакти як у попередній позиції, проте обличчяя партнерів спрямовані ліворуч, а нахил тулуба відсутній; позиція контрпроменада (Counter Promenade hold) - збережено контакти попередніх позицій, партнери дивляться один на одного з нахилом голови праворуч, нахил тулуба відсутній; Відкрита позиція (Open hold) - єдиний контакт - партнер тримає правою рукою ліву руку партнерки, партнери дивляться один на одного без нахилу голови, нахил тулубів також відсутній; Контр відкрита позиція (Counter Open hold) - ліва рука партнера тримає праву руку партнерки (єдиний контакт), положення голови і тулуба як в попередній позиції; Позиція тінь (Shadow hold) - партнерка стоїть перед партнером, трохи праворуч, спиною до нього, лівою рукою партнер тримає ліву руку партнерки, а правою - іï праву руку, погляд спрямований вперед, нахил тулуба відсутній, партнери рухаються з тої самої ноги в одному напрямку; позиція напівтінь (Semi Shadow Hold) - положення партнерів та напрямок руху як і в попередній позиції, проте партнер, тримаючи ліву руку партнерки лівою рукою, праву тримає на передній частині іiі правого стегна, а права рука партнерки спрямована праворуч, лікоть не торкається тулуба; подвійна позиція (double hold) - партнери стоять обличчям один до одного, тримаючись за руки, трохи вище висоти лінії плеча, починаючи рух із протилежних ніг; відкрита розширена позиція (open extended hold) - пара стоїть поруч, обличчям в одному напрямку, партнерка праворуч від партнера, іiі ліву руку він тримає правою рукою на висоті плеча, а вільні руки партнерів витягнуті в сторони на висоті (дозволяються імпровізовані рухи вільними руками в координації з музичним супроводом); позиція фігуристів (skaters hold), зазвичай традиційна позиція в танцях на льоду - пара стоїть поруч, обличчям в одному напрямку, партнер ліворуч від партнерки, тримаючи іiі ліву руку лівою рукою, а праву - правою; позиція ліва рука в правій руці (left hand to right hand open hold) - партнери стоять обличчям один до одного на відстані витягнутих рук, партнер тримає лівою рукою праву руку партнерки, а вільні руки партнерів відведені в бік на висоті плеча; позиція правого рукостискання (right handshake hold) - партнери стоять обличчям один до 
одного на відстані витягнутих рук, партнерка стоїть праворуч від партнера, який тримає ії праву руку своєю правою рукою, а ліві руки - відведені в бік на висоті плеча (Herbison-Evans, 2006).

Регулюючими органами соціального та спортивного танцю Австралії на сучасному етапі є Федеральна асоціація вчителів танців Австралії (з 1936 р.), яка була створена в Сіднеї у 1931 р. під назвою «Товариство танцюристів Нового Південного Уельсу» («The New South Wales Dancers Society»), з 1937 p. - Федеральна асоціація вчителів танців Австралії та Нової Зеландії, метою якої є сприяння процесу навчання соціальним та конкурсним бальним танцям, професійного розвитку танцюристів, збереження та вдосконалення стандартів для викладачів танців, надання екзаменаційних послуг іншим організаціям, пов'язаним із танцювальною освітою та ін. (Federal association teachers of dance, 2016); Австралійська танцювальна рада (Australian Dancing Board) - національний адміністративний орган професійних бальних танців, член Міжнародної ради бальних танців (ICBD), нині Всесвітньої танцювальної ради (WDC) (Australian Dancing Board, 2017); Австралійське танцювальне товариство (Australian Dancing Society) - національна організація, яка була заснована в 1942 р. М. Пауеллом для забезпечення демократичної структури для обслуговування танцювального спорту на континенті. Варто зазначити, що саме за сприянням М. Пауелла, якому належать багато ініціатив з покращення та еволюції бальних танців в Австралії, формування та розвиток стилю Нью-Воуг відбувався на національному рівні з залученням провідних фахівців. Наразі ADS має філії у всіх штатах Австралії та організовує понад 30-ть чемпіонатів та змагань щороку, а серед новаційних ініціатив організації - надання прямої трансляції повної програми чемпіонату ADS Australian DanceSport Championship (Australian Dancing Society 2015).

Наукова новизна. Вперше проведено мистецтвознавче дослідження Австралійського стилю конкурсних спортивних бальних танців Нью-Воуг (New Vogue); визначено особливості формування стилю в історичній ретроспективі та виявлено внесок провідних танцюристів і вчителів бальних танців - членів професійних танцювальних організацій Австралії в процесі його канонізації, розглянуто композиційні особливості та специфіку техніки виконання 15-ти конкурсних танцювальних секвенцій у ритмі Повільного фокстроту, Танго, Віденського Вальсу та Маршу.

Висновки. Визначено особливості австралійського стилю виконання спортивних бальних танців Нью-Воуг та його відмінності від Міжнародного та Американського: усталеність композицій та різноманіття позицій в парі, зокрема роз'єднання партнерів під час виконання танців; використання танцювальними парами відкритих позицій; можливість виконавців змінювати стиль рухів руками відповідно до власної індивідуальності, що сприяє посиленню видовищності виступів та створенню ефектних художніх образів.

\section{Список використаних джерел}

1. Australian Dancing Board. URL : http://www.adb.org.au/aboutus.htm (дата звернення: 13.09.2018).

2. Australian Dancing Society. URL:

http://www.australiandancingsociety.com.au/index.php/about-us (Accessed: 15.09.2018).

3. Boyd N. New Vogue (old time) sequence dancing : the revised technique of twelve championship dances. Turramurra, N.S.W. : N. Boyd, 1979. 96 p. : ill.

4. Boyd N. New Vogue (old time) sequence dancing : the revised technique of six competition dances. Turramurra, N.S.W. : N. Boyd, 1980. 48 p. : ill.

5. Boyd N. Guidelines for technique studies : an analysis of technique used for Standard (Ballroom) dances, New vogue sequence dances, Latin-American dances. Turramurra, N.S.W. : N. Boyd, 2000. $112 \mathrm{p}$.

6. Boyd N. New vogue sequence dancing \& the Viennese waltz: The technique of the championship \& competition dances. Turramurra, N.S.W. : 2006. 192 p. : ill.

7. Boyd N. Nostalgia Part 1. OAM, Australian Dance Review, no. 302, March 2008, pp. 12-21. 
ISSN 2410-1176 (Print) Вісник КНУКіМ. Серія Мистецтвознавство. Вип. 39. ISSN 2616-4183 (Online)

8. Federal association teachers of dance. URL: https://www.fatd.com.au/about (Accessed: 16.09.2018).

9. Herbison-Evans D. Computer Animation of the Merrilyn. 1999. URL: https://app1492098746.000webhostapp.com/vogue/merr.html (Accessed: 16.09.2018).

10. Herbison-Evans D. Holds in the computer animation of New Vogue Dances. 2006. URL : https://donhe.my-free.website/holds (Accessed: 16.09.2018).

11. Hutchinson A. Labanotation or Kinetography Laban: The System of Analyzing and Recording Movement. New York: Theatre Arts Books, 1970. 550 p.

12. Limon C., Butler L. A step by step dance instruction book : 40 new vogue (old time) dances for the Social dancer as they are danced today. Dubbo, N.S.W. : Development \& Advisory Publications for C. Limon, 1986. 156 p. : ill.

13. Limon C., Butler L. Dances for Entertainment. Dubbo, N.S.W. : Development \& Advisory Publications for C. Limon, 1988. p. 156.

\section{References}

1. Australian Dancing Board, [online] Available at: http://www.adb.org.au/aboutus.htm [Accessed 13 September 2018].

2. Australian Dancing Society, [online] Available at: <http://www.australiandancingsociety.com.au/index.php/about-us > [Accessed 15 September 2018].

3. Boyd, N. (1979). New Vogue (old time) sequence dancing: the revised technique of twelve championship dances. Turramurra, N.S.W.: N. Boyd.

4. Boyd, N. (1980). New Vogue (old time) sequence dancing: the revised technique of six competition dances. Turramurra, N.S.W.: N. Boyd.

5. Boyd, N. (2000). Guidelines for technique studies: an analysis of technique used for Standard (Ballroom) dances, New vogue sequence dances, Latin-American dances. Turramurra, N.S.W.: N. Boyd.

6. Boyd, N. (2006). New vogue sequence dancing \& the Viennese waltz: The technique of the championship \& competition dances. Turramurra, N.S.W.: N. Boyd.

7. Boyd, N. (2008). Nostalgia. Part 1. Australian Dance Review, no. 302, March 2008, pp. 12-21.

8. Federal association teachers of dance, [online] Available at: <https://www.fatd.com.au/about> [Accessed 16 September 2018].

9. Herbison-Evans, D. (1999). Computer Animation of the Merrilyn, [online] Available at: <https://app-1492098746.000webhostapp.com/vogue/merr.html> [Accessed 16 September 2018].

10. Herbison-Evans, D. (2006). Holds in the computer animation of New Vogue Dances, [online] Available at: <https://donhe.my-free.website/holds> [Accessed 16 September 2018].

11. Hutchinson, A. (1970). Labanotation or Kinetography Laban: The System of Analyzing and Recording Movement. New York: Theatre Arts Books.

12. Limon, C., Butler, L. (1986). A step by step dance instruction book: 40 new vogue (old time) dances for the Social dancer as they are danced today. Dubbo, N.S.W.: Development \& Advisory Publications for C. Limon.

13. Limon, C., Butler, L. (1988). Dances for Entertainment. Dubbo, N.S.W.: Development \& Advisory Publications for C. Limon.

(С) Павлюк T. С., 2018 